\title{
LEGAL AID: EXISTING LAW, POLICIES AND PRACTICES IN NEPAL
}

\author{
Bimal Prasad Lamichhane
}

\begin{abstract}
Legal aid is a system of providing free or inexpensive advice, assistance, or representation for those who cannot afford to pay for the services of professional lawyers mainly because of a difficult financial situation. The provisions of legal aid to the poor are based on humanitarian considerations and the main aim of these provisions is to help the poverty-stricken people who are socially and economically backward. It can be said that the spiritual essence of the scheme consists in investing law with a human heart to ensure immanence of social justice in the juridical order on the substantive and the procedural planes of law. In this article the author clearly presents the notion of legal aid, its relevance, institutions rendering legal aid services in Nepal and examines the Nepalese scenario, legal provisions, policies, practices as well as the problems of legal aid in Nepal.
\end{abstract}

Keywords: Access, court, equality, justice, lawyer, legal Services

\section{Introduction}

All human beings are born free and equal in dignity and rights (Universal Declaration of Human Rights, 1948, Article 1). Every person should have equal access to justice when their dignity or rights are infringed. Therefore, human dignity is always at risk if a justice system is not able to ensure equal access to justice (Subedi, 2012: 50). Justice is the ultimate need of every human being. The term justice suggests the quality of being just or right or reasonable. Justice is the synthesis of liberty, equality and fraternity. If justice is denied, there is question in the existence of law and law is said to be non-prevailing. So, the state and the 
law it enacts must treat all individuals equally. Justice means fairness in the way people are treated. All citizens are equal in the eyes of law irrespective of their financial position, but economic inequality has made justice beyond the reach of the weaker sections of the people. The effective legal aid program is an operative means in the realization of justice. The concept of legal aid has been inalienable part of human beings because equal protection of law is one important aspect of democracy.

Even in the republican state, justice is not in the access of everyone. Most of the people are not aware about their rights, consequences of their act and legal remedies. Nowadays justice and procedure to achieve justice is too complex, lengthy, time consuming and costly. The poor people having low income are not able to bear the fee of the lawyer and the cost of court in their cases. As a result, they face long imprisonment, heavy fine, depression and lack of self-confidence.

There is need of an overall assessment of the legal aid schemes and the framework that is undertaking the operations and envisioning more effective system that serves broader interests of the deprived communities who are considered to be the recipients of the service. In some situations, due to inability to pay the cost of lawyer and the cost of court administration, guiltless people and victims face severe problems and are punished as well. In such a situation law and legal system lost its motto, mission, schemes, creditability and objectives. Hence, equality, harmony, integrity, tranquility, equal justice cannot be maintained within the legal system. Therefore, legal aid is indispensable to provide equal justice to all.

Access to justice is a crucial and basic human right, which enables individuals to assert and protect many other human rights. The legal profession has a crucial role to play in ensuring access 
to justice, by providing legal services (legal information, legal advice and legal assistance for handling administrative matters and court cases). Individuals of limited means who are not able to pay for legal services, particularly members of disadvantaged, vulnerable and marginalized groups, require special institutional mechanisms and services to ensure their access to justice (Legal Aid Manual, 2009: 3). This includes legal aid schemes. Legal aid performs a crucial role in providing fair and equal access to justice to those who are at risk of being excluded from our legal system. It is quite crucial for the marginalized, disabled, destitute, vulnerable, excluded and economically poor to get access to court, legal services and justice.

Simply, legal aid means legal assistance provided to the needy people. Legal aid is the service which is provided without taking fees to those needy people who are unable to afford the legal service due to several factors such as poverty, illiteracy, disability and so on. It is the aid given to the people who don't have a good access to the justice system. This is a free service given to those who don't have the money or who is not in the financial position to hire a legal professional. The process of giving free legal service to the one who cannot afford it is known as legal aid. According to the principle of natural justice, every one should have access to justice. Hence, to comply with this principle there should be legal aid who cannot afford it.

The general meaning of the term legal aid, therefore, is a social arrangement extending and providing special assistance or help to the poorer and weaker members to enable them enforce their legal rights, facing on an equal platform the powerful and the rich members, through the legal process (Singh, 1996: 02). The provision of legal advice and representation in all those threatened as to their life, liberty, property or reputation who 
are unable to put pay for it (The International Commission of Jurists, 1959). Legal aid is the provision of assistance to people otherwise unable to afford legal representation and access to the court system (Pancholi, 2013: 175). Legal aid is a social assistance or help extended to the one facing a legal problem but not affording, being handicapped by his scare resources and means. It is said that "legal aid does not ensure access to justice for deserving cases, as most people are not eligible. Instead, it provides access to lawyers for an eligible minority" (Boosting Access to Justice for Needy People, 2013: 03). Thus, legal aid is the provision of assistance to people who are unable to afford legal representation and access to court system.

Legal aid means the free legal assistance to the poor and weaker sections of the society at the state cost with the object to enable them to exercise the rights given to them by law in any Judicial Proceedings before the courts or tribunals (Myneni, 2007: 136). The New Encyclopedia Britannica, "Legal aid is the professional legal assistance given, either free or for a nominal sum, to indigent persons in need of such help" (The New Encyclopedia Britannica, 1974: 122).Legal aid is a system of government funding for those who cannot afford to pay for legal advice, assistance and representation. It is a statutory and constitutional system administered by the state. Legal aid is not a charity of gift instead it is matter of rights of the deprived and destitute. It is constitutionally guaranteed right in the fundamental right of the citizens.

According to Section 2(a) of Legal Aid Act 2054 B.S., of Nepal, Legal Aid means legal aid to the indigent person under this Act and the term also includes counseling and other legal services such as correspondence pleadings, preparation of legal documents and proceedings in the courts or offices on behalf of 
indigent person (Legal Aid Act, 2054 B.S, Section 2(a)).Legal Aid Act2054 B.S was enacted to make legal provisions regarding legal aid for those persons who are unable to protect their legal rights due to financial and social reasons to provide for equal justice to all according to the principle of rule of law(Legal Aid Act, 2054 B.S, Preamble).Generally, legal aid could be provided in three kinds they are legal advice or assistance, civil legal aid and criminal legal aid. Thus, legal aid is a kind of legal service, advice, assistance or representation provided through the government funding or through non-governmental organizations to those who cannot afford to pay for it. Legal aid can be provided in pre-trail, trail and post trail stages.

\section{Relevance of Legal Aid}

With the advancement in the system of courts, the adoption of formal procedures made the administration of justice relatively complex. Therefore, lawyer is needed to represent the cases and the lawyer takes certain fees for representing the cases. All the people cannot pay fees for the lawyers, so the concept of legal aid is important. Legal aid is quite important in developing countries like Nepal where there is appalling poverty, ignorance, and illiteracy and the people lack awareness of their rights and means to enforce them. Legal aid plays an instrumental role in accomplishing equality in society and ensure justice in every walk of life.

The legal aid system has provided a great service to many people. But the profession must remember that, when seeking legal aid, they are under a special responsibility, to seek that it is wisely and carefully administered (Denning, 1993: 115). Today legal aid has attracted a worldwide attention. The basic reason for such a broad approval and that too more or less at the same point of time is that the concept of legal aid is firmly fastened to 
the concept of 'rule of law', which has the principle of 'equality before law' as its concomitant (Singh, 1996: 01). Rule of law and equality before law are the fundamental pillars of democracy. Democracy cannot be sustained in the absence of these two pillars. When there is no rule of law in a society, the society will be unmanaged, prevailing, disorder, disturbance, disintegration which no society prefers or can even afford. Unless the common man, whether he is rich or poor is able to assert and vindicate the rights given to him by law. So, to promote democracy the machinery of justice must be readily accessible to all irrespective of their social, economic, biological, geographical, or any other types of variances. So, in order to sustain a faith in the system and democracy, provision of legal aid is indispensable.

Legal aid is important to those who need it and who are unable to exercise and enforce their human rights and other legal rights for want of money and social backwardness. Its relevance is consistent with access to justice for those who are poor having low income and not able to bear the fee of lawyer. So, it is expected to be benefitted for those who are initiating with the spirit of helping hand of deprived people from justice. In the absence of legal aid to the destitute party to litigation, judge can hardly protect the interest. So, that legal aid is an essential ingredient for the process of law. Similarly, in the absence of effective legal aid program, poor people are bound to be deprived of justice. They will not be able to pay the lawyer's charge. Courts will be like a five-star hotel open to all but accessible only to the rich (Legal Aid and Legal Literacy Scheme in Nepal, 1994: 07). Thus, the courts must be for poor people too. So that, legal aid should be provided to the indigent and poor people. Legal aid enables the deprived and downtrodden to enjoy their rights, freedom and liberties. It also promotes public interest by safeguarding the interest of weaker section of the people. In sum we can say Legal Aid: Existing ... Bimal Prasad Lamichhane -26 - 
that the primary purpose of the introduction of the free legal aid scheme was to improve access to legal services at the stage of legal proceedings. This program help ensures fairness in the justice system.

\section{Objective and Methodology}

The objective of this study is to trace out the concept of legal aid, its significance, institutions which provides legal aid and examines the Nepalese scenario, legal provisions, practices as well as the problems of legal aid in Nepal based on the primary and secondary sources. In this study, the author has applied multiresearch methods, techniques and methodology. The author has adopted content analysis and doctrinal research methodology according to need.

The study has extensively been more and more analytical, descriptive, critical as well as historical. Doctrinally, the Constitution of Nepal, its Acts, Rules and Regulations related to legal aid have been used as primary sources. Other information and knowledge have been collected and utilized from secondary sources such as published research works, authorized books, articles and journals. The data of information are descriptively analyzed and analytically explained. Uniform rule of citation has been strictly adhered while citing from authentic books or giving their references. In this research article the author has used APA model citation.

\section{Status and Consequences of Legal Aid in Nepal}

The concept of legal aid as a humanitarian concept is as old as the human civilization and the concept varies from country to country depending on the stage of development and her socioeconomic, political and legal background. Though every legal aid system grows on its own soil, taking from a shape as per 
the need and aspirations of its own people yet the growing and developing system have much to learn from the steps the developed legal aid system had trodden (Singh, 1996: 60). With the advancement in the system of courts, the adoption of formal procedures made the administration of justice relatively complex. Therefore, lawyer is needed to represent the cases and the lawyer takes certain fees for representing the cases. But certain people cannot pay fees for the lawyers, so the concept of legal aid is important. Legal aid is quite important in the developing countries like Nepal where the people are under appalling poverty, ignorance, and illiteracy and the people lack awareness of their rights and means to enforce them. Legal aid plays an instrumental role in accomplishing equality in society and ensure justice in every walk of life.

It is a fact that most of the people in Nepal are uneducated. The government data shows that more than 45 percent of the population are under the poverty line and they are illiterate. Nepal is listed as one of the poorest countries in the world. So, due to the scarcity, destitution, illiteracy the Nepalese people have no knowledge about their rights which are guaranteed by the law and cannot afford the expenses of justice mechanisms. Legal aid for the destitute and the deprived people in Nepal is more important. Legal aid must be delivered to those people who are under the poverty line.

Legal aid is the method adopted to ensure that no one is debarred from professional advice and help because of lack of funds (Rao, 2004: 338). In the absence of legal aid to the destitute party to litigation, the judge can hardly protect their interest. So that legal aid is an essential ingredient for the process of law. Similarly, in the absence of effective legal aid program, poor people are bound to be deprived of justice. They will not be able 
to pay the lawyer charge. Courts will be like a five-star hotel open to all but accessible only to the rich. Thus, 'the courts must be for poor people too. So that legal aid should be provided to the indigent and poor people' (Thapa, 2056: 22). Legal aid enables the deprive and downtrodden to enjoy their rights, freedom and liberties. It also promotes public interest by safeguarding the interest of weaker section of the people. The primary purpose of the introduction of the free legal aid scheme was to improve access to legal services at the stage of legal proceedings. This program helps to ensure fairness in the justice system.

Modern state is a welfare state. In modern time most of the democratic states included provision of legal aid in their constitution. Legal aid gained the status of a state obligation and the legal profession played its role towards the poorest of the poor in Nepalese Society. For ensuring the legal aid separate and specific law is formulated by the parliament of Nepal which is known as Legal Aid Act, 2054 B.S. (1997 A.D.). This Act addresses some of the provision targeted on Article 26(14) of the Constitution of Kingdom of Nepal 2047 B.S. The Preamble of Nepalese Legal Aid Act, 2054 B.S.(1997A.D.) provisioned that, "to protect their legal rights due to financial and social reasons to provide for equal justice to all according to the Principle of Rule of Law" (Preamble, Legal Aid Act, 2054 B.S.) this Act is enacted by the Parliament of Nepal. According to Legal Aid Act, 2054 B.S. and Rule 2055 B.S. person who has the annual income less than the 40, 000 (Forty Thousand) shall only be entitled for legal aid. This Act had been promulgated to regulate the procedures in providing legal aid in Nepal.

The singular provision of legal aid is provisioned under Article 20 of the present Constitution of Nepal 2072 B.S. It made a provision of 'Right relating to Justice' and it stipulates that, 
no person shall be detained in custody without informing him or her of the ground for his or her arrest. Any person who is arrested shall be produced before the adjudicating authority within a period of twenty-four hours of such arrest, excluding the time necessary for the journey from the place of arrest to such authority; and any such person shall not be detained in custody except on the order of such authority. Any person who is arrested shall have the right to consult a legal practitioner of his or her choice from the time of such arrest and to be defended by such legal practitioner. Any consultation made by such person with, and advice given by, his or her legal practitioner shall be confidential. Every person shall have the right to be informed of any proceedings taken against him or her, right to a fair trial by an independent, impartial and competent court or judicial body. In the same manner, the special provision of legal aid is mentioned in Article, 20(10), any indigent party shall have the right to free legal aid in accordance with law(Article 20, Constitution of Nepal 2072 B.S.). Therefore, the Constitution has documented requirement of defense lawyer to give advice as a legal aid to the concerned person.

\section{Institutions Rendering Legal Aid Services in Nepal}

At present time many of the governmental and non-governmental organizations are working in the area of legal aid, justice as well as rights of the prisoners. The role of various institutions in the area of legal aid are discussed hereunder:

\section{Law Courts}

Court is one of the sources of providing legal aid in Nepal. There are three tires of court in Nepal i.e. District court, High court and Supreme Court. Legal aid is available in all courts through stipendiary lawyer (Baitanik Wakil). There is provision 
of stipendiary lawyer in Rule 143 of Supreme Court Regulation, 2074 B.S., Rule 157 of High Court Regulation 2073 B.S. and Rule 101(1) of District Court Regulation 2075 B.S. Stipendiary lawyer provides legal aid including counselling, preparation of legal documents and pleading before the bench.

The Supreme Court Regulation 2074 B.S. make provision of legal aid. It has authorized the Register of the Supreme Court of Nepal to appoint a stipendiary lawyer from among the advocates on the basis of seniority through open and fair competition. The stipendiary lawyer is required to work in the legal aid section of the Supreme Court of Nepal. There are similar provisions of stipendiary lawyer in High Court and District Court Regulation. Both Regulations of High Court and District Court prescribe that the stipendiary lawyer will be appointed among the applicant advocates available.

According to High Court Regulation 2073 B.S. the Chief Judge, concerned Bench or Registrar are authorized to make decision of stipendiary lawyer. In the District Court either a Judge or the Chief Judicial Officer (Shrestedar) decides on managing stipendiary lawyer and legal aid. Presently there are two stipendiary lawyers in the Supreme Court, one stipendiary lawyer in each High Court and District Court. The remuneration of stipendiary lawyer of all three tires of court is prescribed by the Government of Nepal. The duty of stipendiary lawyer according to these various Regulations is to provide legal aid to the helpless, unable, children, poor or prisoner litigants as directed or prescribed by the court.

\section{Civil Society and Non-Governmental Organizations (NGOs)}

After the restoration of democracy in 1990, the constitution adopted the open policy and significant number of voluntary organizations were established in the form of NGOs.Civil 
society is broadly defined as all organizational activity that falls outside the orbits of the government or for-profit sector. Civil society means the entire range of organized groups and institutions that are independent of the state, voluntary and at least to some extent self-generating and self-reliant. It includes non-governmental organizations (NGOs) like independent mass media, think tanks, universities and social and religious groups. It is most commonly said that civil society may be heard more loudly in a democratic process. In democracy participation is a key for achieving consensus on reform and that consensus provides greater ownership of all.

Citizens are the users of the legal and judicial system, and they rely on the system to enforce their property and individual rights. It is, therefore, imperative that civil society groups are key actors in judicial reform, as it can act as a voice for the concerns of the public (Bakolis, 2000: 29). As a group, civil society and NGOs can make governments listen to the voice of destitute victims who are deprived from their rights and who are in search of legal aid and quest of justice. It raises the voice of the voiceless, helpless, handicapped, marginalized, vulnerable and poor in the concerned levels for their access in the justice system. It also monitors for accountable, conscious, responsive, participative, transparent, equitable, inclusive, effective, efficient and independent judiciary and contributes to good governance.

There are various civil society organizations that have been providing legal aid in different parts of the country, especially in support, funding and partnership of various national and international donor agencies. They conduct various awareness, trainings and legal literacy, research programmes in the legal aid, human right issues, justice system and so on. They make partnership with the government for sharing the legal problems 
of the victims.

At present time some of the organizations are established and working in the field of law, human rights, justice, freedom, development, legal aid, rights of the prisoners and other several areas of law in Nepal. They are providing services to the deprived groups of the prisoners and other in need of legal services. Legal Aid \& Consultancy Centre (LACC), Centre for Victim of Torture Nepal (CVICT), Central Women Legal Aid Committee (CWLAC), Centre for Legal Research and Resource Development (CeLRRd), Access to Justice and Advocacy of Rights (AJAR) Nepal, Forum for Protection of People's Rights (PPR) Nepal, Advocacy Forum etc. are some non-governmental organizations working in the area of legal aid in Nepal.

\section{Nepal Bar Association and its Branches}

Nepal Bar Association is an organization of private or defense lawyers which is similar to civil society and Non-governmental organizations. Institutionalization of legal aid service came across with Nepal Bar Association's initiation. Nepal Bar Association and its branches of all the courts of Nepal are important source of legal aid in Nepal which provides legal aid in support of different partners and donors mainly Norwegian Bar and European Commission funded legal aid projects. Access to Justice is one of the principal programs of Nepal Bar Association based on the agreement between Nepal Bar Association and Norwegian Bar Association. The targeted group of the project are the poor, indigent Nepali people including women, children, Dalit, Janajati, Madheshi and marginalized community who cannot afford the cost of the lawyer. With the joint collaboration between Nepal Bar Association and the European Union's Conflict Mitigation Programme II; a Legal Aid Manual had been published. 


\section{Strength and Weaknesses of Legal Aid in Nepal}

Affairs concerning delivery of effective and efficient legal aid services to people with conditions of disenfranchisement and deprivation of rights and freedoms are largely determined by and dependent on the 'system of legal education and legal professionalism'. The stereotypical approach that often looked 'legal aid service delivery to people' oblivious of the 'methods and approaches adopted by the legal education and profession' is still pervasive among individuals, organizations and states' departments (Sangroula, 2007: 214). Legal aid service is never a 'privilege' of the state, but an indispensable right of the people in Nepal, for instance, during 1990, the legal professionals, including judges and state's officials considered 'legal aid as a mercy of the providers' (Sangroula, 2007: 214).

Lawyers view that they are in superior or dominant position in attorney-client relationship. This condition makes them capable to dictate their clients of the remedy and process to follow for. This is especially true when the client is poor and cannot pay fees, or he/she under free legal aid scheme (Sangroula, 2007: 218). Our country Nepal is a developing country where most of the people are living in the rural and remote areas and are under the poverty line as well as illiterate. Constitution guaranteed legal aid as a fundamental right and there is specific Legal Aid Act 2054 B.S. and Legal Aid Rules 2055 B.S. in our country.

Due to the lack of poor economic condition, illiteracy and lack of awareness most of the Nepalese people are deprived from justice. Likewise, majority of population are not aware of their fundamental rights and free legal aid guaranteed by the constitution and other laws. The Legal Aid Act 2054 B.S. and Rules 2055 B.S. seems inadequate and unrealistic to cover the overall aspect, reality and problem of legal aid in Nepal. It lacks 
many prominent provisions being embodied in it according to the nature of Nepalese soil, climate and condition.

In the Legal Aid Rules 2055 B.S. no specific criteria, or the preconditions of the people or situation is mentioned to allow legal aid. Rule 3, 4 and 5 seem to be unsystematic and impractical because the procedure prescribed by these Rules to go on the process to get legal aid are too formal, complex and lengthy. Rule 6 (1) included the provision that any person shall not be entitled legal aid if he has the annual income more than forty thousand rupees. In present context this demarcation is very unscientific, impractical and unreasonable. Thus, this monetary limitation should be made reasonable and practical according to the time and situation and this is against right to equality. It should not be limited to those normally classed as poor but should include a wider income group.

A few expensive lawyers-turned legal aid counsels took legal aid as 'a philanthropic' work-a job done for old-age satisfaction of life. This notion or philosophy adopted a 'nasty appearance' in the 1997 Legal Aid Act that granted power to 'legal aid committee to declare some crimes as not eligible for legal aid'. Subsequently, the Regulations adopted by the said committee declared the crimes of 'terrorism, trafficking of persons and narcotic drugs, rape, etc.' as not eligible for delivery of legal aid services (Sangroula, 2007: 214). Rule 6 (2) of the Legal Aid Rules 2055 B.S. has categorized some of the cases where there can be no legal assistance for the victims involved. This provision seems to be contradictory with the constitutional provisions especially with Article 18-Right to Equality of the Constitution of Nepal, 2072 B.S. There should be no such classification of accused for assisting legal aid. Legal aid should be made as a fundamental right of every accused as well as of 
the other general people and should not remain unenforceable. Therefore, the legislature must have a concrete and consistent vision towards legal aid.

The Supreme Court Regulation, 2074 B.S., High Court Regulation, 2073 B.S. and District Court Regulation, 2052 B.S. has made provisions to provide legal aid to the helpless, unable, poor, children and prisoner litigants as provided by the court but the Regulations and Legal Aid Rules 2055 B.S. have not certainly defined and also not developed clear standards so that the helpless, unable and poor persons who are litigant in a case could be objectively identified and necessary legal aid could be provided to them.

Observations in South Asian and East Asian countries present the existence of the notion phenomenal, which can be taken as one of the serious 'drawbacks to fair trial as well as impartiality in the civil and tort litigation'. This notion is thus considered as an important factor for 'continuous exclusion of disenfranchised and deprived groups from supply and welfare system of the state' (Sangroula, 2007: 214). In reality, the bar are not enthusiastic to accept legal aid as mission of legal profession. In contrast, in countries like Nepal, for instance, law practitioners oppose legal aid programs as 'thieves of their fortune' (Sangroula, 2007: 216). Legal aid has never been taken as bar's obligation to common people. Some professional organizations including Nepal Bar Association, civil society and NGOs have been conducting free legal aid and legal literacy programmes with the support of different national and international agencies and donors. Through all these services and programmes a large number of socio-economically disadvantaged and poor people have been benefited. In a practical sense, the sustainable organizational framework seems lacking and currently there are quite a few 
organizations delivering free legal aid services.

The constitution has guaranteed free legal aid as a fundamental right but there lies a problem in its implementation part. The legal aid programmes launched in this regard is like a periodic project and are confined to the small and urban areas of the country only. Such programmes seems unable to cover the rights and welfare of the indigent people and they have also lots of shortcomings, especially in remote and hilly districts. In addition to this, these districts also lack sufficient number of lawyers as well. The programs launched by Central Legal Aid Committee, Courts, Nepal Bar Association, Civil Societies and NGOs are not adequate. The government seems irresponsible and has not allocated adequate fund for the legal aid.

Nepal Bar Association has not managed adequate sources of funds for providing legal aid. It is not sole independent, has not stable vision and has not able to develop alternative source for legal aid schemes. Almost of all legal aid programs have been conducted by the sponsorship of donors. In absence of foreign sponsorship of the donors or their continuous support specific aims and sustainability of most of the program are lacking. For example, the legal aid program executed by Nepal Bar Association is an example, which could not become sustainable even after 12 years of funding by Norwegian Bar Association.

Similarly, the state made the provision of stipendiary lawyer (Baitanik Wakil) to provide legal aid to the indigent people. But in reality, there is no uniform and established system and practice on appointment of the stipendiary lawyer. In some courts the stipendiary lawyers are appointed on the recommendation of Bar Association, in some courts they are appointed through an open competition by taking written examination and interviews and in others they are appointed merely by the decision of the 
concerned authority.

The stipendiary lawyer system has not been effective and fruitful due to the lack of specialization, lack of precise knowledge on the specific issue and subject matter, lack of proper orientation, training, workshop, skill and capacity building programmes, lack of direction, motivation, control, follow-up mechanisms, lack of competent manpower, short term appointment, minimum facilities and remuneration. Likewise, the stipendiary lawyer (Baitanik Wakil) are not able to provide prompt and qualitative service to the needy people. Not only this they are not sincere and responsible to their work and for whom they are appointed. Stipendiary lawyer (Baitanik Wakil) should be given adequate remuneration for their services under the legal aid scheme.

Due to the appointment of stipendiary lawyer (Baitanik Wakil), every year they may not be sincere and responsible to his/her work. They also lack proper motivation and incentives as well. They must be motivated and inspired to take up legal profession as a service to the needy people and destitute section of the society. Likewise, still many accused persons are denied of access to defense and a fair trial and they are unaware of legal aid provided by Court, Nepal Bar Association (NBA), Central and District Legal Aid Committees, Civil societies and NGOs.

Actually, in Nepalese reality lawyers are less motivated to provide legal aid to the needy people, especially, most of the senior lawyer's neglect to provide free legal aid. In the same manner, Code of Conduct of the lawyers 2051 B.S and Nepal Bar Council has not made compulsory provision of legal aid. To provide legal aid depends on the will and interest of the lawyer. Due to these situations and limitations the goal of legal aid program cannot be achieved and some groups of people especially the destitute and weaker sections of the society are 
becoming the victim of justice.

\section{Conclusion}

Legal aid is essentially a mechanism that enables the poor and the vulnerable sector of society to be able to enforce their legal rights in order to access a fair and equitable justice in the society. In the democratic country, it is an immitigable pre-requisite that all citizens get economic and social justice in one way or another. As long as poverty exists in society legal aid will be necessary to uphold human rights and equality for one and all. Therefore, the state must render legal aid to all, whether rich or poor and should not make any distinction among its people on the basis of wealth, power and prestige.

Impediment in the way to justice leads vulnerable and marginalized towards more vulnerability and marginalization. In the absence of legal aid to the destitute party to litigation, the judge in any court can hardly protect their interests. Therefore, legal aid is an essential ingredient for the implementation of laws in the true sense of their enactment. Absence of legal aid means the deprivation of justice, so necessity of legal aid cannot be ignored. In the present context, the scope and necessity of legal aid is increasing day by day. So, the concerned authority must transform, modify the concerned legal provisions and institutionalize the legal aid by the allocation of sufficient budget, widen their activities and legal aid schemes. They should also give continuity to legal aid services through a follow-up programme. Finally, Nepal Bar Association, Nepal Bar Council, Civil Societies and NGOs must assist the court to extend legal aid schemes on macro basis. 


\section{References}

Bakolis, Maria (2000). Legal and Judicial Development: The Role of Civil Society in the Reform Process, Fordham International Law Journal, 24(6).

Boosting Access to Justice for Needy People (2013). Kathmandu: Nepal Bar Association.

Code of Conduct of the Lawyers (2051 B.S.). Available at http:// nepalbarcouncil.org.np/en/code-of-conduct/, accessed on 7 August 2019.

Denning, Lord (1993). What Next in the Law. New Delhi: Aitya Books Publication.

District Court Regulation (2052 B.S.). Available at http://www. lawcommission.gov.np/np/archives/31183, accessed on 7 August 2019.

High Court Regulation (2073 B.S.). Available at http://www. lawcommission.gov.np/np/archives/19606, accessed on 9 August 2019.1

Legal Aid Act (2054 B.S.). Available at http://www. lawcommission.gov.np/en/wp-content/uploads/2018/10/ legal-aid-act-2054-1997.pdf., accessed on 7 August 2019.

Legal Aid and Legal Literacy Scheme in Nepal (1994). A Report for ICJ/Nepal Section in cooperation with International Commission of Jurists/Geneva, Kathmandu: International Commission of Jurists Nepal Section.

Legal Aid Manual (2009). Kathmandu: Nepal Bar Association.

Legal Aid Rules (2055 B.S.). Available at http://www. lawcommission.gov.np/en/wp-content/uploads/2018/09/ legal-aid-rules-2055-1998.pdf., accessed on 7 August 
2019.

Myneni, S.R. (2007). Public Interest Lawyering, Legal Aid and Para Legal Services. ( $2^{\text {nd }}$ edition), Hyderabad: Asia Law House.

Pancholi, P.V. (2013). Public Interest Litigation: Legal Aid and Para Legal Services. ( $1^{\text {st }}$ edition), New Delhi: Cyber Tech Publications.

Rao, Mamta (2004). Public Interest Litigation, Legal Aid and Lok Adalats. (2nd edition), Lucknow: Eastern Book Company.

Sangroula, Yubaraj (2007). Holistic Approach to Delivery of Legal Aid Services: Beginning from Community Responsive Legal Education and Professionalism, NJA Law Journal, 1(1), Kathmandu: National Judicial Academy.

Singh, Sujan (1996). Legal Aid Human Right to Equality. New Delhi: Deep \& Deep Publications.

Subedi, Nahakul (Special Issue 2012). A Normative Dilemma on Access to Justice: Much Emphasis on ACCESS and Little on JUSTICE-Need to Revisit the Socio-legal Interface, NJA Law Journal, Kathmandu: National Judicial Academy Nepal.

Supreme Court Regulation (2074 B.S.). Available at http://www. lawcommission.gov.np/np/archives/33014, accessed on 9 August 2019.

Thapa, Saraj Raj (2056). Legal Aid Jurisprudence in Nepal problems and Prospective, A Dissertation of LL.M., Kathmandu: Central Department of Law, Nepal Law Campus, Tribhuvan University.

The Constitution of Kingdom of Nepal (2047 B.S.). Available - 41 - Journal of Political Science, Volume XIX 
at https://www.vakilno1.com/saarclaw/nepal/theconstitution-of-the-kingdom-of-nepal-2047-1990.html, accessed on 7 August 2019.

The Constitution of Nepal (2072 B.S.). Government of Nepal, Ministry of Law, Justice and Parliamentary Affairs, Kathmandu: Law Books Management Board.

The Interim Constitution of Nepal (2063 B.S.). Available at https://cffn.ca/2007/03/the-interim-constitution-ofnepal-2063-2007-ad-part-i-english/, accessed on 7 August 2019.

The International Commission of Jurists (1959). Report of Committee IV, Clause X, New Delhi.

The New Encyclopedia Britannica (1974). Vol. VI., available athttps:/www.britannica.com/topic/legal-aid, accessed on 7 August 2019.

Universal Declaration of Human Rights (1948 A.D.). Available at https:/www.un.org/en/universal-declaration-humanrights/, accessed on 7 August 2019. 